Intecoms: Journal of Information Technology and Computer Science

Volume 2 Nomor 2, Desember 2019

e-ISSN : 2614-1574

p-ISSN : 2621-3249

DOI : https://doi.org/10.31539/intecoms.v2i2.811

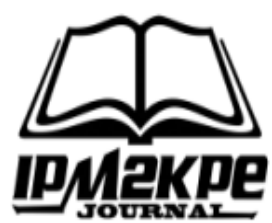

\title{
PEMASANGAN SOLAR CELL UNTUK KAPAL NELAYAN
}

\section{SOLAR CELL INSTALLATION FOR FISHING SHIPS}

\author{
Ali Basrah Pulungan ${ }^{1}$, Juli Sardi $^{2}$, Hastuti $^{3}$, Syaiful Islami $^{4}$, Hamdani $^{5}$ \\ Universitas Negeri Padang ${ }^{1,2,3,4,5}$ \\ alibp@ft.unp.ac.id
}

\begin{abstract}
Utilization of new renewable energy generation technology can encourage the increase of people's prosperity, especially fishermen. This can be done by utilizing solar energy using solar cell as a source of lighting on the fishing vessel's, thus saving the use of fuel oil. Based on the community service activities aimed at reducing the operational costs of fishermen in the form of Solar cell Installation for fishing boats in the Village Air Tawar Barat District Padang Utara. The implementation method that is given is the installation of solar cell in the ship and training maintenance of solar cell and the introduction of components and hand tools. This activity is held for three days which includes preparation, installation and training and followed by two groups of fishermen, each consisting of 3 members. Each group of fishermen received a complete set of solar cells and installed. This activity has been done well and the solar cell is working properly. Participants hope that such activities can be carried out for the next year, as there are still some fishing boats that are in desperate need.
\end{abstract}

Keywords: Solar Cell, Fishing Ships, Groups of Fishermen

\begin{abstract}
ABSTRAK
Pemanfaatan teknologi pembangkit listrik energi baru terbarukan dapat mendorong terjadinya peningkatan kesejahteraan rakyat khususnya nelayan. Hal ini, dapat dilakukan dengan pemanfaatan energi cahaya matahari menggunakan solar cell sebagai sumber penerangan pada kapal kelompok nelayan, sehingga dapat menghemat penggunakan bahan bakar minyak.Berdasarkan itu kegiatan pengabdian kepada masyarakat bertujuan untuk mengurangi biaya operasional nelayan berupa Pemasangan Solar cell untuk kapal kelompok nelayan di Kelurahan Air Tawar Barat Kecamatan Padang Utara. Metode pelaksanaan yang diberikan yaitu melakukan pemasangan solar cell di kapal dan pelatihan pemeliharaan dan perawatan solar cell serta pengenalan komponen-komponen dan hand tools. Kegiatan ini dilaksanakan selama tiga hari yang meliputi persiapan, pemasangan dan pelatihan serta diikuti dua kelompok nelayan yang masing-masing terdiri dari 3 orang anggota. Masing-masing kelompok nelayan menerima satu set solar cell lengkap dan terpasang. Kegiatan ini telah terlaksana dengan baik dan solar cell sudah berfungsi dengan benar.Peserta berharap untuk kegiatan tersebut dapat dilaksanakan untuk tahun berikutnya, karena masih ada beberapa kapal kelompok nelayan yang sangat membutuhkan.
\end{abstract}

Kata Kunci: Solar Cell, Kapal Nelayan, Kelompok Nelayan

\section{PENDAHULUAN}

Sumber energi fosil yang terus menipis dan kebutuhan energi yang terus meningkat, telah mendorong pengembangan dan pemanfaatan sumber energi baru yang lebih efisien dan hijau, seperti angin, mikrohidro, panas bumi, biomassa, biogas dan cahaya matahari. Cahaya matahari telah dimanfaatkan manusia sejak lama sebagai sumber energi dengan menggunakan berbagai teknologi mulai dari sederhana sampai yang canggih. Hal ini disebabkan bahwa matahari sebagai sumber energi yang dapat mensuplai energi sekitar 27.000 kali jumlah energi yang dihasilkan dari semua sumber lainnya (Catalin, 2009). Teknologi saat ini memungkinkan konversi radiasi matahari menjadi energi listrik yang dikenal sebagai sistem fotovoltaik. Sistem konversi ini 
diharapkan dapat memberikan kontribusi signifikan untuk memecahkan beberapa masalah energi yang dihadapi dunia saat ini.

Pertumbuhan konsumsi energi di Indonesia rata-rata $8.1 \%$ pertahun, belum berimbang dengan pertumbuhan pembangkitan energi listrik yang hanya tumbuh rata-rata $5.2 \%$ per tahun (RUPTL 2016). Ketergantungan terhadap energi fosil masih tinggi yaitu $95.4 \%$, cadangannya semakin terbatas. Pemanfaatan sumber energi baru terbarukan adalah salah satu alternatif untuk menggantikan posisi energi fosil. Energi surya sebagai sumber energi terbarukan dapat dikembangkan untuk pembangkit tenaga listrik yang berdiri sendiri atau disalurkan melalui jaringan listrik secara interkoneksi terutama pada daerah katulistiwa khususnya Indonesia (Yandi, Syafii, and Pulungan 2017).

Indonesia berada di daerah tropis mempunyai potensi energi surya sangat besar sekitar rata-rata $4,8 \mathrm{kWh} / \mathrm{m} 2 /$ hari atau setara dengan $112.000 \mathrm{GWp}$, namun yang sudah dimanfaatkan baru sekitar 71,02 MWp baik yang terintrkoneksi dan off-grid (Republik Indonesia 2015). Selain itu, pada daerah tropis variasi sudut azimuth sinar matahari kecil (Loschi, Iano, and Leon 2015), sehingga khusus pemasangan di atas atap kapal nelayan tidak dibutuhkan solar tracking.

Pemanfaatan energi baru terbarukan juga dapat dikembangkan bagi nelayan yang sehari-harinya berada di pesisir pantai dengan tingkat pencahayaan matahari yang sangat tinggi. Kota Padang merupakan salah satu kota besar di Indonesia yang terletak di pesisir barat Pulau Sumatera dengan garis pantai sepanjang $84 \mathrm{~km}$ dan luas wilayah perairan sekitar 720 $\mathrm{km} 2$. Menurut data BPS, jumlah penduduk Kota Padang yang berprofesi sebagai nelayan pada tahun 2016 adalah 7076 jiwa yang tersebar di tujuh kecamatan. Kelurahan Air Tawar Barat merupakan salah satu kelurahan yang terletak di Kecamatan Padang Utara Kota Padang. Kecamatan Padang Utara 2014-2019 diketahui Jumlah penduduk di Kelurahan Air Tawar Barat adalah 15.748 jiwa dan merupakan yang terbesar jika dibandingkan dengan jumlah penduduk kelurahan lain yang ada di Kecamatan Padang Utara. Secara umum, dilihat dari infrastruktur, sarana dan prasarana yang ada sudah bagus dan lengkap.Jalan-jalan umumnya sudah diaspal dan kualitasnya cukup baik (RESTRA Kecamatan Padang Utara Tahun 2014-2019 n.d.).

Jumlah keluarga yang termasuk kategori pra sejahtera dan sejahtera 1 masih tinggi yaitu sebesar 421 keluarga. Kawasan yang paling banyak terdapat masyarakat miskin di Kelurahan Air Tawar Barat berada di sepanjang pesisir pantai Umumnya mereka berprofesi sebagai nelayan dan disana juga banyak terdapat anak putus sekolah, selain itu banyak juga ditemukan pemuda usia produktif yang tidak bekerja (pengangguran). Untuk itu perlu berbagai upaya untuk meningkatkan pendapatan dan kualitas hidup masyarakat yang terdapat pada kelurahan tersebut.

Lokasi kampus pusat Universitas Negeri Padang terletak di Kelurahan Air Tawar Barat yang merupakan lokasi mitra nelayan yang akan menjadi sasaran kegiatan. Universitas Negeri Padang sebagai salah satu perguruan tinggi pendidikan dan vokasi terkemuka di Indonesia, memiliki pengalaman yang panjang dalam pelaksanaan kegiatan pengabdian kepada masyarakat sebagai wujud peran aktif untuk membantu mengatasi berbagai permasalahan yang ada pada masyarakat (Sardi \& Pulungan 2019). 
Dalam hal ini, tim pengabdian merencanakan melaksanakan kegiatan untuk para nelayan berupa pelatihan dan pemasangan panel surya (solar cell) untuk kapal nelayan di Kelurahan Air Tawar Barat. Kegiatan pemasangan solar cell ini dilaksanakan berdasarkan pertimbangan bahwa ketersedian sinar matahari yang banyak sepanjang tahun, energi ramah lingkungan, tidak adanya biaya investasi lahan dan mengurangi ketergantungan akan energi fosil (Hagerman, Jaramillo, and Morgan 2016; Yondri et al, 2017).

Kegiatan ini bertujuan mengurangi biaya operasional nelayan berupa kebutuhan bahan bakar minyak solar khususnya untuk penerangan. Penggunaan solar cell ini nantinya dapat dimanfaatkan dengan baik sehingga akan meningkatkan penghasilan nelayan.

\section{METODE PENELITAN}

Dari permasalahan yang diuraikan tersebut terdapat peluang pemasangan solar cell pada kapal nelayan. Solar cell adalah alat konversi energi matahari menjadi energi listrik, sistem ini, dapat mengurangi ketergantungan akan bahan bakar fosil sehingga penggunaannya dapat sebagai salah satu alternatif untuk mengurangi biaya operasional ketika pergi melaut untuk menangkap ikan (Krismadinata, Aprilwan, dan Pulungan 2019).

Metode pendekatan yang ditawarkan adalah memberikan pelatihan langsung pemasangan solar cell pada kapal nelayan. Kegiatan ini akan memberikan pengenalan komponen-komponen dan hand toolsyang digunakan pada pemasangan solar cell dan rangkaian antar komponen serta penggunaanya ketika dipakai pada kapal sampai menghasilkan energi listrik.
Panel surya dipasang di atap kapal secara horizontal dengan tujuan agar radiasi sinar matahari yang diperoleh maksimum sehingga didapatkan output tegangan yang optimal.

Sistem pembangkit listrik menngunakan solar cell terdiri dari solar cell (panel surya), charger controller, baterai, saklar dan bohlam lampu

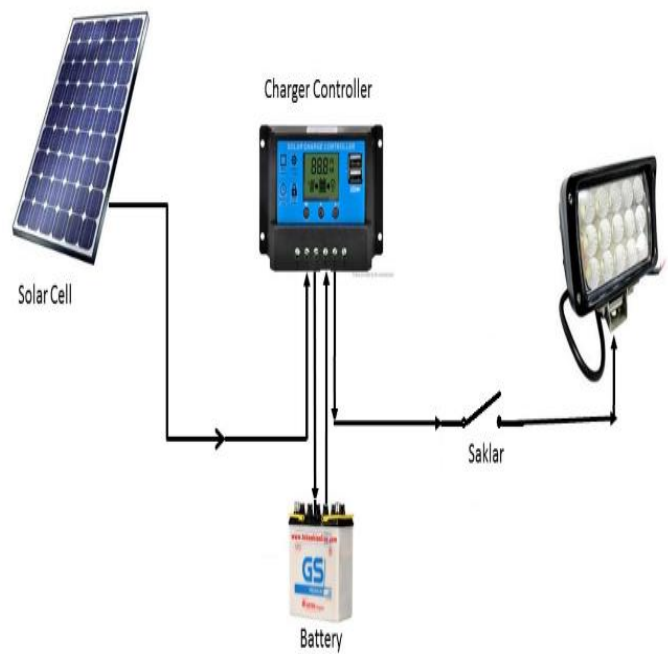

Gambar. 1 Skema Rangkaian Pembangkit Listrik Menggunakan Solar Cell

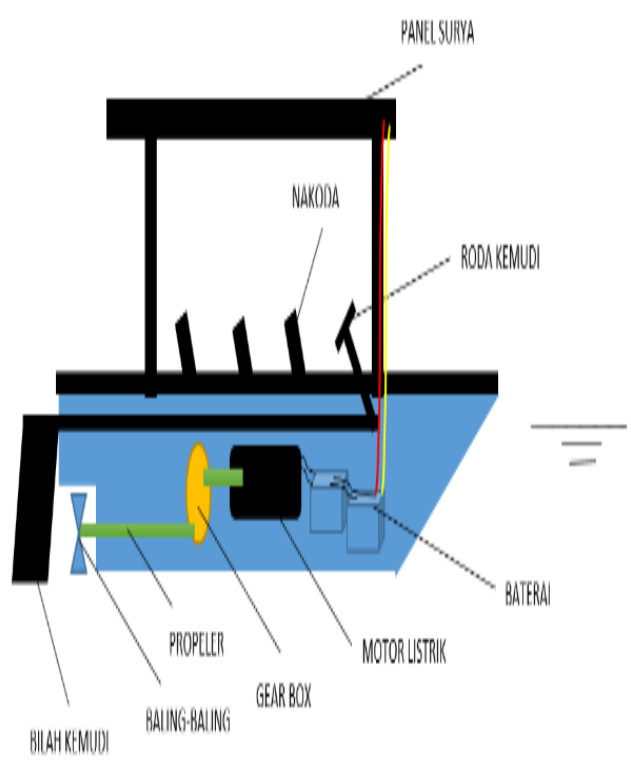

Gambar. 2 Skema Pemasangan Panel Surya (Solar cell) pada Kapal Nelayan 
Tabel 1. Spesifikasi Komponen Sistem Solar Cell yang Digunakan

\begin{tabular}{cllc}
\hline No & $\begin{array}{c}\text { Nama } \\
\text { Barang }\end{array}$ & $\begin{array}{l}\text { Peralatan } \\
\text { Spesifikasi }\end{array}$ & Volume \\
\hline & $\begin{array}{l}\text { Paket PV, } \\
\text { Kabel Twin } \\
\text { 18m, Triplek }\end{array}$ & $\begin{array}{l}\text { Greentek } \\
\text { 100wp }\end{array}$ & $\begin{array}{l}\text { Mono, } \\
\text { VS1024AU }\end{array}$ \\
2. & $\begin{array}{l}\text { Baterai } \\
\text { Xenjepit }\end{array}$ & Xp.NS60 & 2 \\
3. & $\begin{array}{l}\text { Baterai } \\
\text { Bohlam }\end{array}$ & LED12V & 4 \\
4. & Lampu & DC/6W & 6 \\
\hline
\end{tabular}

Rencana kegiatan yang dilakukan adalah sebagai berikut: Pengenalan komponen dan fungsinya, pemasangan dan perawatan solar cell, penggunaan hand toolspada pemasangan solar cell, pelaksanaan pemasangan solar cell pada atap kapal dan pengujian dan pengukuran besaran yang dihasilkan seperti tegangan dan arus.

\section{HASIL DAN PEMBAHASAN}

Kegiatan pengabdian kepada masyarakat ini telah dilaksanakan dengan baik pada tanggal $12-14$ Oktober 2017 dan diikuti oleh satu kelompok nelayan, pelaksanaan kegiatan berjalan lancar sebagaimana yang direncanakan hal ini terlihat dengan tepasangnya solar cell di dua kapal kelompok nelayan. Hasil yang diperoleh dari kegiatan dapat diuraikan dalam beberapa aspek, seperti aspek pengetahuan, keterampilan dan produk.

Berdasarkan diskusi dan tanya jawab yang dilakukan dengan anggota nelayan selama pelaksanaan kegiatan menunjukkan adanya peningkatan pengetahuan tentang pemanfaatan sumber energi baru terbarukan seperti sinar matahari dengan menggunakan panel surya. Nelayan juga dapat mengetahui nilai tegangan yang terdapat pada baterai dan yang ditunjukkan pada charger controller. Peningkatan keterampilan juga dapat terlihat dari pengamatan pada saat pemasangan, para anggota nelayan antusias untuk dapat melakukan pemasangan sendiri, seperti pangawatan pada baterai dan charger controller.

Pengujian produk yaitu pengujian sistem penerangan menggunakan solar cell yang telah dipasang. Setelah selesai pemasangan pada masing-masing kapal nelayan, dilakukan pengujian dengan tujuan untuk memastikan bahwa solar cell telah bekerja dan berfungsi baik, hal ini dibuktikan dengan telah menyala lampu sebagai beban dan telah terjadi pengisian pada baterai. Pengujian dilakukan pada cuaca cerah suhu $25^{\circ} \mathrm{C}$, dengan tegangan yang terukur pada saat itu 14 volt, arus 0,5 A untuk beban 6 watt. Berdasarkan hasil pengujian tersebut menunjukkan bahwa sistem solar cell telah bekerja sesuai parameter yang seharusnya.

Berikut ini beberapa dokumentasi kegiatan:

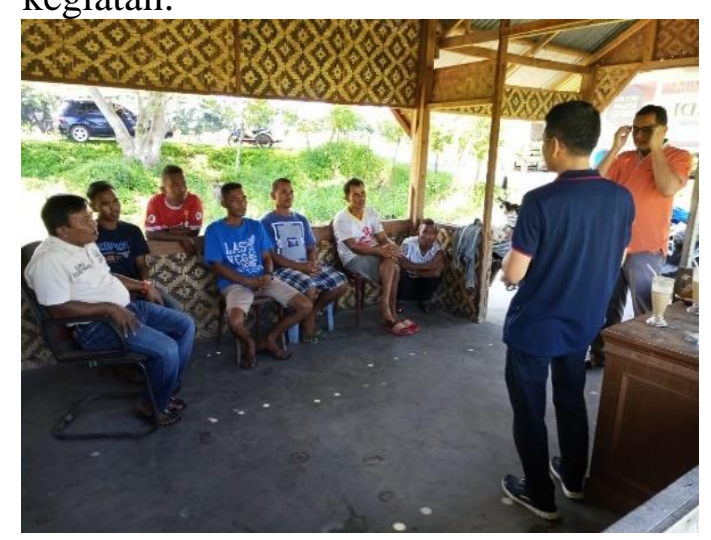

Gambar. 3 Pemberian Materi Sumber Energi Baru dan Terbarukan

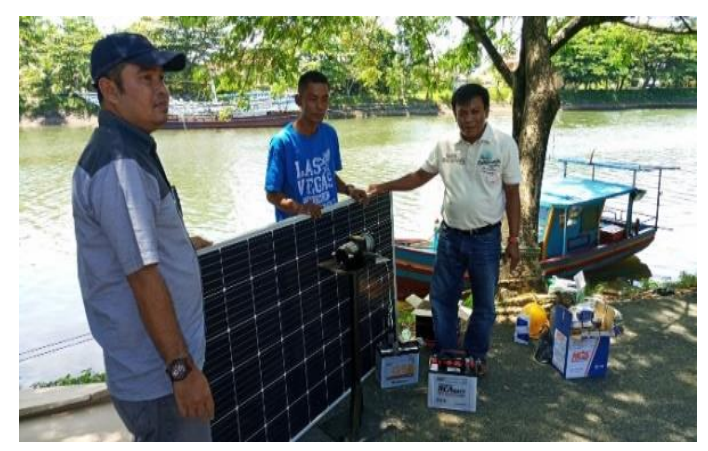

Gambar. 4 Serah Terima Peralatan 


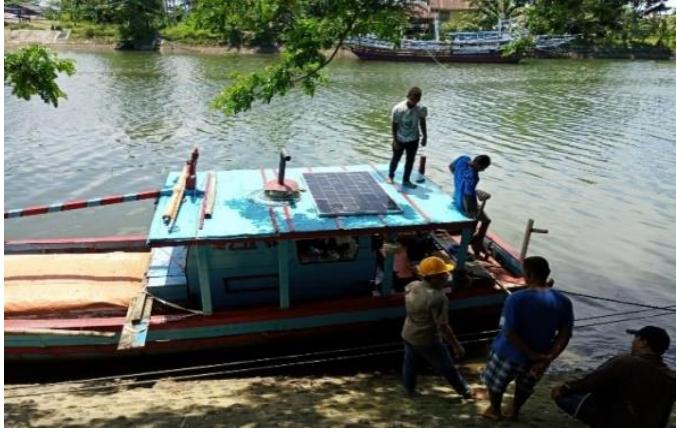

Gambar. 5 Pemasangan solar cell di kapal nelayan

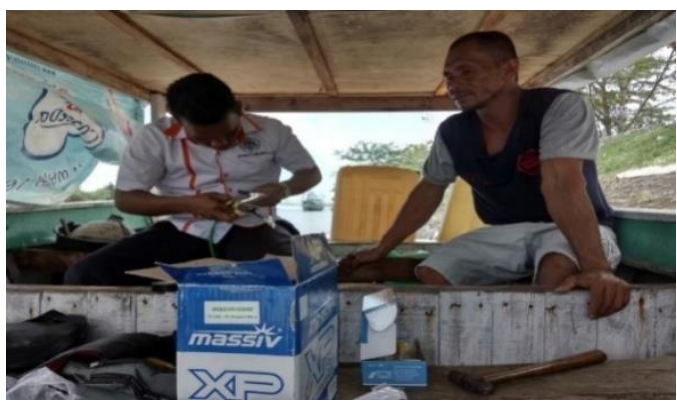

Gambar6 6 Pemasangan Baterai dan Kontroler oleh Nelayan dan Tim Pengabdian

Selama pelaksanaan pelatihan para peserta sangat antusias dan tidak ditemukan kendala yang berarti.Para peserta telah dapat mengoperasikan sistem solar cell yang telah terpasang.

\section{SIMPULAN}

Kegiatan pelatihan dan pemasangan solar cell pada kapal nelayan telah selesai dilaksanakan, dan telah dilakukan pengujian dan pengukuran besaran yang ada.Berdasarkan hasil tersebut, solar cell dan seluruh komponen lainnya telah berfungsi dengan baik dan benar serta telah dapat dipergunakan oleh kelompok nelayan.

\section{DAFTAR PUSTAKA}

Catalin, A. (2009). The Design and Optimization of a Photovoltaic Tracking Mechanism. Portugal: Lisbon

Hagerman, S., Jaramillo, P., \& Granger, M.(2016). Is Rooftop Solar PV at Socket Parity without Subsidier. Energy Policy, 89: 89-94

Krismadinata, A., \& Pulungan, A. B. (2019). Rancang Bangun Sistem Monitoring Simulator Modul Surya. In Prosiding-Seminar Nasional Teknik Elektro UIN Sunan Gunung Djati Bandung, 192-201

Loschi, H. J., Yuzo, I., \& Julio, L. (2015). A Review on Photovoltaic System: Mechanisms and Methods for Irradiation Tracking and Prediction. Smart Grid and Renewable Energy, 6, 187-208

Republik Indonesia. (2015). Rencana Strategis Kementrian Energi dan Sumber Daya Mineral (Renstra KESDM)

Restra Kecamatan Padang Utara Tahun 2014-2019

RUPTL. (2016). Rencana Usaha Penyedia Tenaga Listrik PT PLN (Persero) Tahun 2016 S.d. 2025

Sardi, J., \& Pulungan, A. B. (2019). Pelatihan Reparasi dan Perawatan Alat Listrik Rumah Tangga untuk Pemuda Pesisir. Jurnal Pengabdian dan Perberdayaan Masyarakat, 3(1), 3-6

Yandi, W. S., \& Pulungan, A. B. (2017). Tracker Tiga Posisi Panel Surya untuk Peningkatan Konversi Energi dengan Catu Daya Rendah. Jurnal Nasional Teknik Elektro, 6(3), 159-67 
2019. Intecoms: Journal of Information Technology and Computer Science 2 (2): 53-58

Yondri, S. (2017). Utilization of

Potential Water Energy in

Irrigation Channels for Pico-

Hydro Power Plant. In

International Conference of

Applied Science on Engineering,

Business, Linguistics and

Information Technology 